IZA DP No. 8119

A Survey of the Role of Fiscal Policy in Addressing Income Inequality, Poverty Reduction and Inclusive Growth

Almas Heshmati

Jungsuk Kim

April 2014 


\title{
A Survey of the Role of Fiscal Policy in Addressing Income Inequality, Poverty Reduction and Inclusive Growth
}

\author{
Almas Heshmati \\ Sogang University \\ and IZA \\ Jungsuk Kim \\ Sogang University
}

Discussion Paper No. 8119

April 2014

IZA

P.O. Box 7240

53072 Bonn

Germany

Phone: +49-228-3894-0

Fax: +49-228-3894-180

E-mail: iza@iza.org

\begin{abstract}
Any opinions expressed here are those of the author(s) and not those of IZA. Research published in this series may include views on policy, but the institute itself takes no institutional policy positions. The IZA research network is committed to the IZA Guiding Principles of Research Integrity.

The Institute for the Study of Labor (IZA) in Bonn is a local and virtual international research center and a place of communication between science, politics and business. IZA is an independent nonprofit organization supported by Deutsche Post Foundation. The center is associated with the University of Bonn and offers a stimulating research environment through its international network, workshops and conferences, data service, project support, research visits and doctoral program. IZA engages in (i) original and internationally competitive research in all fields of labor economics, (ii) development of policy concepts, and (iii) dissemination of research results and concepts to the interested public.
\end{abstract}

IZA Discussion Papers often represent preliminary work and are circulated to encourage discussion. Citation of such a paper should account for its provisional character. A revised version may be available directly from the author. 


\title{
ABSTRACT
}

\section{A Survey of the Role of Fiscal Policy in Addressing Income Inequality, Poverty Reduction and Inclusive Growth}

\begin{abstract}
A growing concern on widening income gap between the rich and the poor, the policy mismatch in tackling the relative poverty and income inequality have invited increasing volumes of research focusing on the nexus between equity and efficient growth. Developed countries have experienced the critical challenges and trade-off between their generous welfares provisions and economic growth. Developing countries on the other hand, especially countries in Asia are in the process of shifting their policy direction toward more inclusive growth where most members are transforming themselves from a low-income country into a middle income country (ADB, 2014). This has stimulated the need to understand causes of inequality and poverty for better formulate policies of fostering inclusive growth. Economic growth itself is an important source of welfare distribution in most developing Asian countries. Asian governments used many forms of fiscal policy to mitigate income gaps and poverty because they will substantially undermine the economic growth if left unchecked (ADB, 2014). The objective of this study is to review the previous studies, particularly literatures related with inclusive growth of advanced economies, and to offer an efficient policy options for Asian countries. Major determinant factors of growing inequality, poverty and a range of fiscal policy tools are evaluated from both country and cross-country perspectives. The initiated policy measures are based on experiences of advanced welfare economies and the lessons derived from them will be a meaningful guideline for Asian countries to achieve their goals of inclusive growth.
\end{abstract}

JEL Classification: D63, E62, I32, I38, J68, O47, P46

Keywords: income inequality, poverty reduction, equity, inclusive growth, fiscal policy, developing Asia, advanced welfare economies

Corresponding author:

Department of Economics

Sogang University

35 Baekbeom-ro (Sinsu-dong \#1)

Mapo-gu, Seoul 121-742

South Korea

E-mail: heshmati@sogang.ac.kr 


\section{Introduction}

One of the nucleus macroeconomic objectives in recent decades has been the economic growth with promoting equity. The widening income gap between the rich and the poor has stimulated the need to understand the roots of inequality and poverty, and to construct apposite policies that trim down poverty levels and narrow the income gaps. A series of fiscal policy designed to tackle the growing income inequality and poverty has been competitively introduced from countries at all stages of development and income. (ADB, 2014) These factors, without proper supervision, will eventually undermine the strength of the economies and cause an economic instability and possibly even social unrest (Stiglitz, 2012a). Depending on their economic growth pattern and fiscal constraints, each government can intervene and promote equity with a range of economic measure, mainly tax and benefit system. Unemployment plays a critical role in creating higher levels of inequality and poverty. In an attempt to overcome the threat that unemployment poses, governments have used remedies that foster employability such as stimulating aggregate demand through policies of monetary, fiscal and labor market intervention. Provision of re-training schemes and welfareto-work schemes are the first-rate examples that would encourage active labor market participation.

The research on inequality, poverty and their link with economic growth is voluminous. Many suggests that economic growth itself reduces poverty while amplifies inequality in the initial developing stage. The negative or a rather slow economic growth in recent years has deteriorated the equity. This has called an increased interest in fiscal policy and its impact on the progressivity, distributive effects. Succeeding volumes of research on the issue of inclusive growth has been dynamically released especially issues of widened income gap between the high and low skilled. It does reflect a high demands from the public for equitable distribution of economic growth. In order to bridge the needs of economic growth, which is still the top priority of policy agenda in Asian economy, and equitable sharing the fruits of economic growth, countries in this region need to learn from the previous experiences of advanced welfare economies, where our main focus and objective of this literature study are anchored with.

The rest of this survey is organized as follows. In Section 2 we review the literature on income inequality by focusing on its measurement and determinants including skill biased technical change, polarization, returns to education, globalization and financial market, labor market institutions, inequality trend and fiscal policy instruments. Fiscal policy in both advanced and developing Asian countries are discussed in Sections 3 and 4. Section 5 is on poverty reduction, its relationship with economic growth, reductions trend, measurements and policy effects. The final section summarizes and provides policy implications of the results for developing Asia.

\section{Income Inequality Measurement and Determinants}

A growing concern on widening income gap between the rich and the poor, the policy mismatch in tackling the relative poverty and income inequality have invited volumes of studies from researchers, international and national organizations.

According to Stiglitz (2012a), "Inequality undermines the strength of the economy and contributes to economic instability”. In recent times its importance, especially after witnessing the Wall Street movement, inequality issue has fired countries to pay an immediate attention on addressing the problems and to prioritize it as an urgent policy agenda. The determinant factors of income inequality, a larger part of the literature centered at 
earning inequality related to: (i) skill-biased technical change (SBTC) and polarization, (ii) returns to education, (iii) globalization and financial market, (iv) labor market institutions and (v) inequality trend. Recently other factors have been added to this list, including immigration and finances. These measurements and the role of selected determinants are explained below.

\subsection{Measurement of Income Inequality}

Estimation of income inequality is dependent on the indicators used for the estimation as well as the inclusion of other control variables to the model. Some studies present an alternative way to improve the analysis. Knight and Sabot (1983) proposed a way to quantify the effects between education and income gap. They used a model that incorporated two groups of workers, low-educated (low-wage) and highly educated (high-wage) workers. The effect of a rise in the number of highly educated workers on income inequality was attributed from two components: the pure composition effect and the relative returns to education.

Gottschalk and Huynh (2010) measured inequality and mobility based on self-reported earnings. They found clear links between non-classical measurement error and various measures of inequality and mobility. Findings based on matched tax records have shown that the effects of non-classical measurement error are extensive but negated when estimating mobility.

When estimate income gaps for the groups of $90^{\text {th }}$ in percentile below, making a distinction between men and women should be considered. A 90/10 income ratio for women has increased by more than double the increase of men. In order to figure out the primary cause of income inequality, one must not only be concerned with economy developments over time but also changes in means and distribution of income (Gordon and Becker, 2008). Atkinson et al. (2011), using data of 22 countries including European, North American and Asian countries, find that despite top income groups share a small portion of the population, it share a great portion of total income and total taxes paid by this group is quite high. Aggregate economic growth per capita and Gini indexes can be thus very sensitive to the inclusion of top incomes.

According to the study of Wade (2004) who used China's income statistics, income inequality has been falling when measured with PPP, weighted by population and averaging coefficient (e.g. Gini index). The inequality trend has widened otherwise. Nolan et al. (2011) found key issues of how best to approach the measurement of income and wage inequality. It focuses on several inequality measurements, the definition of income, the income recipient unit, and the unit of analysis used to capture inequality. For a multi-level analysis based on aggregate inequality, a sound identification of comparable hypotheses, classifications across countries and links to data sources and levels should be built-in.

The estimated results of income inequality are varied by the selection of data and indicators.Very often, quite contradicting results can be derived depending on inclusion of certain definitions, variables or modeling. In order to identify the primary cause of income inequality, one must carefully specify the various sources of inequality such as how the economy develops over time, the changes in means and distribution of income, etc.

\subsection{Skill- Biased Technical Change and Polarization}

The question if productivity determines the workers' pay has long been an important research subject in inequality literature. One of the predominant views on identifying the main causes 
of growing inequality are increased demand for high skilled workers in recent times, whereas the reverse trend holds for lower skill level workers. "For example, technological progress will disproportionately benefit richer and better-educated population groups, who are more comfortable with new technologies' (ADB, 2014). Such argument has been challenged by several authors (Card and DiNardo, 2002: Piketty and Saez, 2001). Simultaneously, attention has sharply increased on the issue of the top income group's share on total income. (Bastagli et al., 2012). Gordon and Becker (2008) provide a comprehensive survey of seven aspects of rising inequality by arguing that SBTC accounts the major part of increased skewness of labor incomes at the top. Their key argument is that worker's jobs at the top and bottom income level are hardly outsourced while relatively easy substitution can be done at the works of middle income group.

Antonczyk et al. (2010) compare trends in wage inequality in the U.S. and Germany, find the two countries showed a high increase of wage inequality between 1979 and 2004. The interaction effect between the SBTC and institutional factors explains the dissimilar inequality trends across two countries. In another study Bowlus and Robin (2012) compare earning inequality and mobility across the U.S., Canada, France, Germany and the U.K. during the late 1990s. Their study divulged that earnings mobility and employment risk are positively correlated with the base-year inequality. Peñalosa (2010) questioned whether growth and inequality are moving in the same direction although her main argument is that output growth is achieved as a consequence of increases in physical capital, human capital, employment or the level of technology. She addressed that each of these factors acted to shape the relationship between growth and inequality.

Previously Piketty and Saez (2001) presented a new justification for the trends associated with the top income groups in the U.S. for the period of 1913 to 1998. The results showed that top income and wage shares display a U-shaped pattern throughout the observed period. Their findings indicated 'technical change' alone cannot fully explain the cause and feature of growing income gap. The shocks capital owners had experienced during Great Depression and World War II seemed to have a permanent effect on income inequality. A high degree of progressive taxation and reduction in the rate of wealth accumulation at top of the distribution were addressed as plausible explanations to the low recovery rate from these shocks.

Chiswick et al. (2006), using tax statistics, reviewed the major findings of volumes of study on top income and wealth shares series over the $20^{\text {th }}$ century. They find that in the first part of the century, due to wars and depression shocks, resulted in a dramatic plunge in rates of top income earners which did not recover in the immediate post war decades. Later Atkinson and Leigh (2010) proposed that the shares of the very richest exhibit a strikingly similar pattern, falling in the three decades after World War II, before rising sharply from the mid-1970s onwards. Atkinson and Morelli (2012) also found that top gross income shares fell from 1914 to the 1970s; but since 1979 have more than doubled. The similar has been confirmed by Atkinson et al. (2011)'s literature survey, comprehensive reviews on the volumes of studies in the field of shares of high-level incomes using income tax statistics. Results are in line with those above.

Lemieux (2007) reviews recent developments in the literature on wage inequality, with a special focus on the top end of the wage distribution. Using data from the PSID, it is demonstrated that the growth in performance-pay jobs, attributed to development of ICT, investment in education and greater social mobility has put in substantially to the rise in wage inequality in the U.S. between late 1970s and the early 1990s. Prieto-Rodríguez and GabrielRodríguez (2010) also analyzed the relationship between income and social mobility from a 
regional perspective with samples from 14 European countries. The results conformed to the findings from previous studies (e.g. Prieto-Rodríguez et al., 2008) that the within education group component of wage inequality is much more imperative than the between component. Kenworthy and Smeeding (2013) address the new phenomenon of the income inequality trend in the U.S. These embrace an increasing trend of polarization between the two political parties and the enhanced political influence of the rich on the fiscal policy.

Atkinson (2007) questioned if the solid increase in the relative demand for skilled labor and the growing exposure of unskilled workers during the process of globalization, can clarify the cause of widening earnings inequality in OECD countries since 1980. The author argues that this single elucidation cannot uncover the important aspects of the earning inequality across countries, and greater earnings dispersion at the top of the distribution. Atkinson suggests a new approach which can supplement evaluation of the race between technology and education. Although there are some counter arguments in terms of the "extent of the impact", most of the STBC studies have at home that SBTC can explicate some portion of recent trends in growing income inequality.

\subsection{Returns to Education}

Gregorio and Lee (2002) empirically test the relationship between education and income distribution of a broad range of countries for the period of 1960 and 1990. Findings revealed that educational factors, such as the attainment of higher education, a more balanced distribution of education and public spending, have contributed significantly to the equalization of income distribution. They also confirmed the Kuznets Inverted U-curve for the relationship between income level and income inequality. However, the critical extent of cross-country variation in income inequality remains unexplained.

Chiswick (2003) reviews Jacob Mincer's (1974) contributions to the analyses of human capital and earnings and the distribution of incomes by focusing on labor market experience or on-the-job training. The Mincer' earnings function is the predominant tool used in large numbers empirical studies. For instance, Belzil (2007) performs estimation of a reduced-form dynamic model of the transition from one grade level to the next. After conditioning on skill heterogeneity, it is found that the effect of schooling and experience coexists. Martins and Pereira (2004) propose possible education related explanations for the higher returns among high-income workers.

Peñalosa (2010) found that growth reduce an inequality of relative wages through the opportunity of education, technological change by lowering earnings inequality; whilst faster technology-driven growth results the greater earning inequality when technical change is skill-biased. The Lemieux (2006) study shows that for the U.S., returns to post-secondary education have increased over time, with sharp leap for higher-income workers than those of lower incomes. Most of the growth in wage inequality between 1973 and 2005 was due to increases in the returns to post-secondary education.

Manafia and Marinescu (2013) explore the influence of investment in training on various macroeconomic indexes for the EU countries, grouped into 3 clusters based on labor market regulations and unemployment level. A positive correlation between vulnerability during the recent crisis and the fastest increases in unemployment rates were explored. The Governments, by investing more in lifelong learning and trainings, can help its workers better adapt to the demands of a changing labor market. On the other hand, studies by Checchi (2000) Sylwester (2000), Hendel et al. (2005) and Kenworthy and Smeeding (2013) provided a different perspective by showing that expenditure on education does not affect economic 
growth nor does it improve income inequality.

In the Checchi (2000) study, a strong negative relationship between average years of schooling and income inequality is uncovered. The relationship appears U-shape with a lower turning point at 6.5 years. The test results show that income inequality is also negatively correlated to per capita income and positively associated with capital/output ratio and government expenditure on education. Hendel et al. (2005) show that policy that facilitates education be more affordable would enlarge the income inequality. The study confirmed that reducing financial constraints for postsecondary education and reduction in interest rates can increase wage gaps and inequality.

Sylwester (2000) empirically examines whether allocating more resources to education can underpin the income distributive effect within a country. Expanding public expenditures for education clearly reduce the income inequality and such result was robust with inclusion of various control variables. The larger effect was captured in high income nations. Teulings and Rens (2005) estimated the effect of private returns of education to social return, measured by GDP. The results demonstrated that, it is quite intricate to ascertain of education effect on GDP. No apparent answer has supported dynamics in the private return. Kenworthy and Smeeding (2013) finds less extent of verification as to the correlation between rising income inequality and widening social gradients among different level of education groups.

Several studies have looked at the relationship between education and income inequality. Some found that increases in an individual's human capital raise its productivity lead to increases in potential income levels, while others addressed that education alone cannot be the ground of income inequality. Other factors such as an individual's innate capability and working experience were recommended to be incorporated to the analysis while the problem of quantifying those factors is still left unsolved. Overall, many empirical analysis of the effects of education to inequality exhibited mixed views. Nonetheless, high fraction of literatures arrived at the finding that education is one of the crucial determinants of an individual's earning potential as well as the profitable income-equalizing tools.

\subsection{Globalization and Financial Market}

According to Gordon and Becker (2008), the economic growth from expansion of international trade is negative or less distributive because low-paid foreign workers do compete with domestic workers, and that greater import penetration has pushed wages downwards. Wade (2004) tested whether the neoliberal argument, for instance World Bank's claims about the benign effects of globalization on growth, poverty and income distribution, can be empirically valid and the answer was no. The range in pay rates within manufacturing has steadily increased since the early 1980s, while absolute income gaps are widened fast.

Bergh and Nilsson (2010) examined if trade openness and the economic freedom shape income inequality within the country. First, their investigation supports the perception that policy reforms favoring trade openness have on average amplified income inequality in recent decades. In line with theoretical predictions of the relationship between economic liberalization and income inequality at different levels of development, the negative effect only appeared in middle- and high-income contexts. Second, policy reforms facilitating deregulation and social globalization on average showed a non-equalizing distributional impact. The coefficient of economic globalization shows increase of income inequality but the result was prone to have selection bias depends on sampling countries. Third, in estimating a dynamic model which treated endogenous problems, the studies authenticated that trade liberalization and economic globalization raise income inequality. 
Stockhammer (2013) studied the source of the substantial fall of wage shares, addressing the negative effects of finances, welfare state retrenchment and globalization. Technological change has brought about a positive influence on wage shares in developing economies, but a negative influence in advanced economies. Globalization in production has showed extensive negative effects, even in developing economies. In a more recent study, Asteriou et al. (2014) investigate the relationship between income inequality and globalization. The results implied that, financial globalization through FDI, has expanded inequality in the EU-27 since 1995. The Rada and Kiefle (2013) study on four decades of income distribution and economic activity for 13 OECD countries, confirmed that globalization has a negative effect on wage share. On the other hand, Agnello and Sousa (2012) showed that an increase in the degree of trade openness endorse greater equality because trade can promote a more equal distribution of income.

Some studies showed how income inequality has increased as a result of a banking crisis. Stiglitz (2012b) argues that "uneven income distribution undermined U.S. household's consumption" and "the financial market failure was the main cause of the economic downturn”. While Milanovic (2009) and Stockhammer (2012) claim that the roots of the recent crisis are due to the long-run structural changes in income distribution. Furthermore, Bellttini and Delbono (2013) view that the majority of crises that occurred between 1982 and 2008 have been preceded by high levels of income inequality while Atkinson and Morelli (2011) found no clear links between increases in income inequality and systemic banking crises. Bellttini and Ddelbono's analysis (2013) shows interrelation is robust when inclusion of Gini values for incomes after-tax as well as before-tax and transfers. Beck et al. (2007) found that financial development increase the income levels of the poorest quintile therefore reducing income inequality.

Studies such as Mookerjee and Kalipioni (2010) had empirically measured the impact of the availability of financial services on income inequality. The greater access to bank branches strongly reduced income inequality. Agnello and Sousa (2012) assessed the impact of financial reforms on income inequality and confirmed the removal of policies aimed towards directed credit and excessively high reserve requirements led to improvements in the securities market, which in turn led to reductions in inequality. Bonfiglioli (2012) analyzed the relationship between investor protection and income inequality and found the rapport as non-monotonic. Freeman (2010) advocated institutions and experts had failed to detect rising risk levels in the deregulated financial sector. A high degree of income inequality was attributed as one of the crucial causes for the global financial crisis.

Globalization, especially trade expansion which served as the springboard for countries rapid growth benefits some firms and households while it impairs others.(ADO, 2014) Such uneven distributive effect has often been victimized as major source of widening income inequality. Market opening led low-paid foreign workers directly compete with domestic workers, and that greater import penetration has pushed down wages of domestic workers. A number of studies suggest that financial and social globalization and deregulation have led to greater inequality. Some, however, still view that world poverty and income inequality have fallen due to the higher levels of economic integration. Financial development, such as better bank access was seen as a desirable mechanism for reducing inequality. Since the massive bailout and stimulus packages used to stabilize the crisis failed to retrieving the force of economic growth, the urgent need for financial system reform is recommended. 


\subsection{Labor Market Institutions}

Hendel et al. (2005) specifically focused on which labor market institutions affect inequality. The labor market components affect relative wages, the labor and capital shares, and the unemployment rate simultaneously, which in turn affects the distribution of personal incomes; "however the overall impact remains equivocal." (Hendel et al., 2005) It is found that a higher minimum wage decreases inequality, but led high unemployment, the crucial cause of income inequality. Therefore, should the latter effect be dominant, it will result in a positive correlation between minimum wage and income inequality. No result, supporting direct or indirect effects of the unemployment benefit on the distribution of income was reported.

Lemieux (2007) discuss studies on labor market institutions whereby workers paid for performance are relatively less likely to belong to unions or to be paid around the minimum wage. While the fall in unionization and the real value of minimum wages may have caused wages gap, the growing rate of performance-pay has produced a somewhat similar outcome for workers located in a higher tier of the income distribution. Checchi and Peñalosa (2008) using a panel data of OECD countries for the period 1960-2000 found the high degree of wage bargaining coordination under strong unionization increase income inequality. Personal income inequality is a function of the wage differential, labor share, and the unemployment rate and labor market institutions affect income inequality through these channels but their overall effect is theoretically ambiguous. The high capital-labor ratios are linked with higher unemployment and consequently with a more dispersed distribution of income.

According to the literature surveys conducted by Gordon and Becker (2009), quantitative evidence in the studies exhibits a rather small role for the decline in unionization, but only for men. The effects of various institutions on inequality can be better estimated using the experience of different countries by allowing informed policy choices to be made in the future. Sologon and O'Donoghue (2009) estimated the impact of labor market policies and institutional factors on earnings mobility. Unionization increases earnings mobility, and relative high unemployment benefits would imply a relative low willingness to accept a lower paid job. Peñalosa (2010) found that strong labor market institutions not only reduce inequality but also increase employment and economic growth.

Lee and Saez (2012) made a theoretical analysis of optimal minimum wage policy. They concluded that policies for minimum wage and subsidies for low-skilled workers are complementary. The findings implied that in the short-run, the Stiglitz (1982) type of response is perceived as skills that are exogenous and have high occupation mobility. However, in the long run, it is more practical that individuals choose their occupation based on after-tax rewards. Rada and Kiefle (2013) by examining the long run dynamics in income distribution and economic activity for a panel of 13 OECD countries found unionization to have a pro-labor effect. Kenworthy and Smeeding (2013) found the minimum wage in the U.S. is determined by the government rather than collective bargaining. Despite the steady rise in income inequality, the minimum wage was allowed to fall in real terms.

A higher minimum wage has been widely considered as one of the factors that affect earnings distribution and the unemployment rate. Several studies show that the high degree of wage bargaining coordination under strong unionization negatively affects inequality. Gürtzgen (2009) using a linked employer-employee data set, analyzed the relationship between firm profitability and wages in Germany. In this research, there are indications that individual wages are affected by firm-specific and industry-wide wage contracts neglected in some 
studies listed above. However, different estimation methods confirm that accounting for unobserved individual and establishment heterogeneity point to a coefficient of zero.

\subsection{Inequality Trend}

The evolution of income inequality over recent decades has been explored by several studies and reviewing the background of fiscal policy and the effectiveness of previously implemented polices would better channel for deriving an appropriate policy options for future.

Jäntti (1997) uses data from Luxembourg Income Study on developed countries. Increases in labor earnings inequality has primarily caused an increase in household income inequality in Sweden, the U.K., and the U.S. The key determinant of the evolution of inequality amongst U.K. households is mobility in factor shares. However, the influence of various factors on overall inequality differs across countries. Self-employment income in the U.K. and Canada, and income from property in the Scandinavian economies are found as main sources of overall inequality in income. These results have shown that it is challenging to generalize the causes of distributional changes.

Bowlus and Robin (2012) compared earnings inequality and mobility across the US, Canada, France, Germany and the U.K. during the late 1990s. They used a model of earnings dynamics and found that earnings mobility and employment risk are positively correlated with base-year inequality. However, Gordon and Becker (2008) found no distinctive changes in labor's share of national income over the last two decades, once a consistent cyclical chronology is applied. Rada and Kiefle (2013) exerted analysis on four decades of cyclical and long run dynamics in income distribution and economic activity for a panel of 13 OECD countries. The business cycle has been estimated as weakly profit-led, and that long-run equilibrium has been deviating towards a lower wage share.

Gottschalk et al. (2008) estimate the trend in the transitory variance of male earnings in the U.S. from 1991 to 2005 using unemployment insurance data. Despite substantial differences between the LEHD and the PSID in the levels of male earnings, the changes over time are transitory variances. Especially during the 1991-2003 periods, transitory variances fell then rose slightly. In a nutshell, the analysis of the LEHD data confirmed that the findings based on the PSID showed neither trend nor cycle over the period. Antonczyk et al. (2010) compares trends in wage inequality in the U.S. and Germany and empirical results show that the two countries showed a high degree of wage inequality increases and difference in patterns between 1979 and 2004.

Peñalosa (2010) studied whether growth is in tandem with income inequality and deems that output growth is achieved as a consequence of increases in physical capital, human capital, employment or the level of technology, and argues that each of these factors help to shape the relationship between growth and inequality. Inequality displays both a positive incentive effect and a negative opportunity creation effect on growth rates. Woo (2011) estimated the relationship between inequality and growth using a relatively large sample of countries. They present a strong supportive result about the negative link between inequality and growth over the period of 1960-2000.

Smeeding and Thompson (2010) using surveys of consumer finances data found that the impact of the great recession on inequality is ambiguous. Because three crises in the housing, stock markets and mass job losses affected incomes across the entire distribution, the overall impact on inequality is difficult to verify. The combined impact of the three crises after 2007 led to a decline in income inequality at the top of the income distribution. Despite declining 
from a 2007 peak, however, inequality remains high. They find a rising share of income accruing to real capital or wealth from 1989 to 2007. Atkinson et al. (2011) found that most countries experienced plunge in top income shares in the first part of the 20th century due to shocks to top capital incomes during the wars and depression.

Osberg (2013) shows that that the top 1\% and bottom 99\% in the U.S. and Canada have had divergent market income growth rates since the 1980s. According to the author, increasing economic instability in Canada and the U.S. is an implication of increasing inequality. Stockhammer (2013) studied the cause of substantial falls in wage shares using panel data for 71 countries from 1970 to 2007. He found that wage shares have fallen substantially over the past 25 years. This is part of a trend towards increasing inequality. Adjusted wage shares have declined in both OECD and developing countries.

From a household earnings perspective, the higher wage inequality, the greater the household income inequality. The impact of the financial crisis on inequality is imprecise. Because financial crises affect incomes across the entire distribution, its overall impact on inequality is difficult to verify. The output growth is achieved as a consequence of increases in physical capital, human capital, employment or change in technology. Each of these factors helps to contour the relationship between growth and inequality and its development patterns.

\section{Fiscal Policy in Advanced Economies}

Fiscal policy, i.e. direct income tax and transfers, exercised by advanced economies in general, have been proved to be distributive and progressive. Some studies have uncovered the fact that there is a positive relationship between fiscal consolidations and an increase in the income gap, which includes the European Monetary Union effect on income inequality. There are mixed views on the effect of fiscal policy on income inequality at one fell swoop. This section reviews the various topics of income inequality, economic growth, fiscal consolidation and other effects of fiscal policies implemented by advanced economies.

\subsection{Income Inequality Effects of Fiscal Policies}

Wolff and Zacharias (2007) assess the effects of U.S. government expenditures and taxation on household between the years 1989 and 2000. Incorporating the estimates of net government expenditures into a wealth-adjusted measure of income, the study finds that the overall income inequality declined significantly in line with net government expenditures. Analyzing the breakdowns suggested that expenditures, as compared to taxes, yield greater inequality-reduction results.

Alesina and Ardagna (2009) examined the cases of fiscal stimuli and fiscal adjustments in OECD countries from 1970 to 2007. It concludes that fiscal adjustments based on spending cuts accompanied by tax cuts is the most successful form of policy adaption. Kitao (2010) tested whether temporary fiscal policy, tax-cut and rebate transfer, to stimulate economic activities can enhance an economic recovery. A reduction in income taxation stipulates an immediate incentive to work and save more, which in turn raises aggregate output and consumption. Both policies improve the overall welfare of households and the rebate policy benefits especially for low-income households.

Peñalosa (2010) argues that fiscal policy can affect both economic growth and income distribution. Muinelo-Gallo and Roca-Sagalés (2011) examine the impact of different fiscal policy instruments on economic growth and income inequality of the 43 upper-middle and high-income countries over the period 1972-2006. Increase in public investment is proved to 
reduce inequality without harming output while larger current expenditures and direct taxes diminish economic growth and reduce inequality. A similar upshot has been presented by Muinelo-Gallo and Roca-Sagalés (2013) for 21 high-income OECD countries during the same period. Distributive expenditures and direct taxes deteriorate GDP growth and net income inequality. Cutting non-distributive expenditure is divulged as the most adequate fiscal policy to facilitate GDP growth and reduce income inequality simultaneously.

Bargain (2012) applied micro-simulations to quantify the relative effects of fiscal policy and checking the sensitivity of the policy effect. Should reforms of income support and tax credits not be implemented, inequality and poverty depth can be amplified and a sharp drop in child poverty would not eventuate. Silva et al. (2013) studied how large fiscal multipliers in Europe are, for both spending and revenue variables with annual data from 1998 to 2008. The results recommended that during a recession period the public spending multiplier is positive whereas during a high inflation period it is smaller, and perhaps even negative. The effectiveness of the tax multiplier is shown to be greater in recessions while consolidation phases negatively affect the size of multipliers.

Peñalosa and Orgiazzi (2013) used data from the Luxembourg Income Study to examine some of the forces that have driven changes in household income inequality over the last three decades of the twentieth century. Study covered income inequality for six developed countries and found that earnings distribution is one important driving force behind recent trends. On several occasions, greater earnings dispersion has minimized its impact on overall household income inequality. As in Jäntti (1997), in some countries the contribution of selfemployment income and increases in inequality in capital income account for a substantial fraction of the observed distributional changes.

Thompson and Smeeding (2013) explore trends in inequality and poverty using both market and after-tax and transfer income during and after the Great Recession. Using market income, inequality and poverty rose sharply between 2008 and 2010. The primary exception is measures for the top of the distribution, where tax and transfer policies lowered inequality and poverty, but those policies were not the same across the entire population. Poverty declined among the elderly, changed little among children, and rose sharply among the working-age. Inequality fell across the total population, but there was no change among working-age households.

In sum, government expenditures, when compared to taxes, yield greater inequality-reducing results. The fiscal adjustments based on spending cuts accompanied by tax cuts has been proposed as one of the successful forms of policy for reducing inequality and facilitating GDP growth simultaneously.

\subsection{Improved Growth Effects of Fiscal Policy}

In general, the increases in government revenue that occur as a result of economic growth allow the government to employ policies that promote more jobs and swell benefits in kinds. In this regard, fiscal consolidation can be rather regressive and less distributive although mixed outcomes have been presented in some cases.

In a comprehensive study, Carre're and De Melo (2012) provided a cross country analysis of the correlation between fiscal policy and growth for 118 developing and 22 high income OECD countries during the period of 1972-2005. The study found that a growth event is more likely to occur when there is a fiscal event. In the case of a typical developing country, the probability of an occurrence of a fiscal event is high for the bottom half of the income 
distribution, but the probability that this fiscal event is followed by a growth event is higher for the third quartiles. This findings are consistent with the view that the success of a growthoriented fiscal expenditure plan for developing countries depends on their institutional environment.

Mertens and Ravn (2013) estimate the dynamic effects of changes in taxes in the U.S. by distinguishing between the effects of changes in personal and corporate income taxes. The result suggests different types of taxes should be distinguished when estimating their growth impacts. European Commission (2013) reported that fiscal devaluation has only a limited and short-lived expansionary effect on employment and GDP. The fiscal devaluation has a regressive effect to workers regardless of types of changes in the VAT rate. Tax swap cannot be the substitute for structural reforms needed for addressing causes of external imbalances and poor growth. The repeated use of consumption tax will eventually grind down the credibility of the government and minimize the effectiveness of the reform.

Kuttner and Posen (2002) investigated the effectiveness of Japanese fiscal policy over the 1976-1999 period by analyzing real GDP, tax revenues and public expenditures. The expansionary fiscal policy, in form of tax cuts or increased public expenditure, does stimulate the economy substantially. The results implied that a tax cut multiplier is $25 \%$ higher for a four-year horizon than that of public spending. Historical data showed that Japanese fiscal policy was contractionary in the 1990s leading to a significant variation in growth. Most increases in public debt were associated with declining tax revenues from the recession.

The effects of fiscal policy responses in 118 episodes of banking crisis in advanced and emerging market countries is examined by Baldacci et al. (2009). Timely countercyclical fiscal measures shorten the length of crisis episodes by stimulating aggregate demand. Fiscal expansions that support government consumption are more effective in decreasing crisis duration than those based on public investment or income tax cuts. Devereux et al. (2013) studied how Pigouvian levies on bank liabilities associated with systemic risk have affected European banks capital structures. In a related study, Göndör and Nistor (2012) empirically studied the relationship between FDI and fiscal policy and found that fiscal policy affects the competition environment and is a crucial factor affecting FDI.

Brzozowski and Gorzelak (2010) provided evidence on the impact of balanced budget and debt rules on the degree of fiscal policy volatility. Motivated by previous studies, which showed a negative and robust correlation of fiscal policy volatility and long run growth, they tried to identify the possible determinants of such a correlation. They concluded that fiscal rules have a significant impact on fiscal policy volatility, but depending on the target, public debt or fiscal balance, the rules will increase or decrease policy volatility.

A sound fiscal policy stimulates both FDI and economic growth, which in turn indirectly improves income inequality. The increases in government revenues that occur as a result of economic growth allows the government to implement policies that are conductive to business environments, promote more jobs and increase the benefit in kinds.

\subsection{Financial Consolidation Effects of Fiscal Polcies}

When introducing fiscal policy options, a key challenge is how to fiscal policy generates economy growth which in turn indirectly improves income inequality. A central concern lies on how to leverage fiscal policy for more inclusive growth while minimizing fiscal constraint. Fiscal consolidation is creation of contraction strategies for minimizing deficits and preventing the accumulation of more public debt. Larch (2012) finds that to run deficits across the cycle, so called deficit bias, is predominantly attributed to the 'common pool' 
problem especially for developed and middle-income countries, which externalizes the costs for society as a whole thereby overspending. According to the study, the relationship between income distribution and fiscal performance is indirect. He concludes that failing to address issues of income distribution may lead to unfavorable sustainability outcomes.

The Rada and Kiefle (2013) study of dynamics in income distribution and economic activity for a panel of 13 OECD countries, show that contractionary monetary policy, R\&D spending and more financialization, shift from production to finance, have a negative effect on the labor's welfare. OECD (2013) reported that fiscal consolidation would make governments' policy goals elsewhere more complicated. Fiscal consolidation would slow the process of global rebalancing, undermine long-term growth and aggravate income inequality. The report recommended an implementing of consolidation strategies that minimize these adverse sideeffects.

Cottarelli and Jaramillo (2013) discussed the ongoing debate as to trade-off between fiscal policy and economic growth. Stabilizing public debt-to-GDP shows a penalizing effect to potential growth, which in turn would make it harder to sustain high public debt over the longer run. Thus, lowering public debt over time is inevitable. In the short-run, however, front-loaded fiscal adjustment is likely to hurt growth prospects, which would delay improvements in fiscal indicators, including deficits, debt, and financing costs.

Bouvet (2010) used data from 197 European regions between 1977 and 2003 and found that while income inequality has been decreased within richer countries, convergence criteria of the single market exacerbated regional inequality in poorer EU countries. Bertola (2010) argues that Europe's EMU had a relatively petite impact on income inequality due to its less munificent social policies. Conducting independent fiscal policies and enforcing income redistribution schemes became more difficult for National governments.

In a recent study, Agnello and Sousa (2012) assess the impact of fiscal consolidation on income inequality. A panel analysis of 18 industrialized countries from 1978 to 2009 shows significant rises income inequality during periods of fiscal consolidation. In addition, while fiscal policy driven by spending cuts seems to be detrimental for income distribution while tax hikes have an equalizing effect. The fiscal consolidation program shows quantitative impacts on income inequality. When consolidation plans represent a small share of GDP, the income gap widens, affecting households at the bottom of the income distribution. Considering the linkages between banking crises and fiscal consolidation, they found that the income gap effect is amplified when fiscal adjustments take place after the resolution of such financial turmoil.

In the short-run, front-loaded fiscal adjustments are likely to hurt growth prospects, which would delay improvements in fiscal indicators, including deficits, debt, and financing costs. A number of studies addressed that the relationship between income distribution and fiscal performance is indirect. Income inequality rises during periods of fiscal consolidation. The income gap widens, strongly affecting households at the bottom of the income distribution.

\subsection{Other Views on Effects of Fiscal Policies}

There are other effects than inequality and growth from fiscal policy and its consolidation. The Ardagna (2007) study looked at an economy that contained unionized labor markets and heterogeneous agents. Changes in macroeconomics and distributional consequences in response to the various fiscal policy implementations are examined. The author suggested that when employment in the private sector and capital stock fall, the economy contracts. Simulations implied that debt financed policy initiatives increases public employment, and 
wages and unemployment benefits increases workers' utility in the short-run. The negative effect of expansions in public employment are mitigated if public spending enters the production function. In another study, Benetrix (2012) studied the impact of fiscal shocks in a panel of 11 EMU countries and provided empirical evidence on the effects of different types of spending on real wages. The result shows that an increase in government spending raises the real wage with variable impact depending on the spending type.

Atkinson and Leigh (2010) used taxation data to create the distribution of top incomes covering five Anglo-Saxon countries of relatively similar backgrounds and tax systems. They find that a reduction in the marginal tax rate on wage and investment incomes increase the share of the top percentile group. Peñalosa and Turnovsky (2011) examined how changes in tax policies affect the dynamics of distributions of wealth and income. They investigated the impact of recent tax changes in the U.S. and Europe. Tax changes that affect working hours will affect wealth and income distributions, which in turn will either reinforce or offset the redistributive impact of taxes. Considering financing government expenditure, they found that with policies that reduce the labor supply and output, they also lead to a more equal distribution of after-tax income.

Beetsma et al. (2013) studied budgetary planning and implementation in the Netherlands over the period 1958-2009. The key findings are related to: planned surplus variability across terms, trend-based budgeting planning process, positive association between expected growth and public debt and how strict the budget plans will be. Kenworthy and Smeeding (2013) by analyzing U.S. data found that actual changes in tax or transfer policy did not raise inequality, government transfers and economic growth but merely kept up with inflation.

Policies that redistribute income in favor of only one particular type of worker are found to be detrimental to the workers as a group. While tax changes that affect working hours will affect wealth and income distribution, which in turn will either reinforce or offset the direct redistributive impact of taxes. Some studies showed that tax changes or transfer based policies had little effect on stemming the rise in inequality. Government transfers only keep up with the level of inflation, rather than making any contribution to economic growth.

\section{Fiscal Policy in Asia}

"Historically in Asia, the role of fiscal policy has been to facilitate economic growth by providing basic infrastructure while safeguarding macroeconomic stability. A tradition of fiscal prudence was instrumental in Asia's past success, along with public investments in growth conducive physical and human”. (ADB, 2014)

Jomo (2006) argues that both rapid growth and structural change have reduced poverty in a number of East Asian economies. Income inequality has been low in Korea and Taiwan, but has risen in recent years. Contrary to Kuznets' hypothesis, the cases of Korea and Taiwan suggest that lower inequality can be complementary to rapid growth in early stages. In Thailand, Malaysia and Indonesia, despite different policies, poverty has declined, while income inequality trends have varied. With openness and sustained rapid growth, China has experienced increased inequality despite considerable poverty reduction. These suggest that inequality tends to worsen with economic liberalization in the absence of redistribution.

Using the Atkinson inequality measure of income distribution, Sato and Fukushige (2010) analyze the impact of China's income inequality on total income inequality among ASEAN countries. They found that China's domestic income inequality worsened income inequality among East Asian countries from the 1980s, and this effect became even more prominent 
from 1990. The growth of China's per capita GDP had an equalizing effect on income distribution initially, but was reversed around 1997. Although economic growth of China has improved income inequality it has had a more equalizing effect overall.

The ADB's (2012) research on financing Asian higher education for inclusive growth, have traditionally dominated debates on measures of financing higher education. Privatization of education is a pivotal component of the analysis. The study deliberately links the financing of higher education to questions of equity. Any higher education system that fails to cultivate the breadth of talent in society is sacrificing both quality and efficiency. The failure to make progress on inclusive growth is resulting in lower growth and higher inequalities. This issue is further emphasized in the ADB Outlook (2012) report suggesting that Asia's rapid growth in recent decades has led to a significant reduction in extreme poverty, but it has also been accompanied by rising inequality in many countries. Since the income inequality coexists with non-income inequality, it contrasts with the "growth with equity" characteristics. Since technological progress has favored capital over labor, the declining labor income share has resulted in rising inequality. In many Asian countries income inequality is due to uneven growth and unequal access to opportunity.

Claus et al. (2012) assesses the impact of fiscal policies on income inequality in Asia. In order to discuss the role and effectiveness of taxation and government expenditure on income distribution, it conducts analysis over the 1970-2009 periods. Even though tax systems tend to be progressive, government expenditures are a more effective tool for redistributing income. Both social protection spending and government expenditure on housing appear to increase income inequality. Rodgers and Zveglich (2012) examine gender inequality in labor markets in Asia and the Pacific, with a focus on the structural drivers of women's labor force participation. In Asia's lower-income countries, economic necessity is an important push factor behind women's employment. China and Taiwan have been successful in conducting policies to support women in market-based activities.

Kar and Saha (2012) conducted analysis on recent Latin America studies and argued that as the size of the informal economy grows, corruption is less harmful to inequality. They investigated if the Latin American environment applies to cases for developing countries in Asia where corruption, inequality and shadow economies are large. Both the corruption and risk guide indices are sensitive to a number of important macroeconomic variables. Although corruption increases inequality in the absence of the shadow economy, the income inequality tends to fall as there are larger shadow economies in South Asia.

Balakrishnan et al. (2013) assesses how pro-poor and inclusive Asia's recent growth has been, and what factors have been driving these outcomes. It finds that while poverty has fallen across the region over the last two decades, inequality has increased. Compared to other regions and to Asia's own past, the recent period of growth has been both less inclusive and less pro-poor. A number of fiscal policies are suggested to broaden the benefits of growth. These include increase in spending on health, education, and social safety nets; labor market reforms to boost the labor share of total income; and to make financial systems more inclusive. Yoshida et al. (2014) reviews different projection methods and estimates the global poverty rate of 3 percent by 2030. The study argues that accelerating growth is not enough and that sharing prosperity is essential in order to end extreme poverty in one generation.

Cornia and Martorano (2013) focus on the income inequality changes that have taken place in a few representative developing regions during the last 30 years. While inequality rose in the majority of the countries in the 1980s and 1990s, the last decade was characterized by divided inequality trends. With contrasting the experience of virtuous regions and non-virtuous regions, the difference in inequality trends was likely due to institutional factors and public 
policies. Tests conducted confirmed that a reduction in inequality levels is possible if appropriate macroeconomic, labor, fiscal and social policies are adopted by governments.

In many Southeast Asian economies, market liberalization policies and sustained economic growth platforms have led to both declines in poverty levels and variations in inequality trends. For some countries increased inequality levels have been experienced despite considerable poverty reduction. Several studies showed that income inequality tends to worsen with economic liberalization, especially in the absence of effective provisions for redistribution systems. Some suggested that a reduction in inequality levels is possible even during an economic liberalization process, given appropriate policies are adopted by governments.

\section{Poverty Reductions Policies}

In recent decades, the greater efforts and ranges of new policy measures, at the national and international levels, have led to major success in lowering the global poverty rate (UN, 2013). According to the UNDP (2013), the number of extreme poor has dropped by 650 million in the last three decades. However, human poverty is still prevalent in some parts of the world. During the processes of globalization and national developments, a large portion of the population had yet to experience the benefits of economic growth and social development and many still suffer extreme poverty. Along with income inequality, one of the major challenges that Asian countries are facing is the issue of poverty. Without properly addressing poverty issues, the region may encounter trouble in achieving its sustainable economic growth and developmental objectives.

A large number of studies are reviewed here, which cover an assortment of issues of ongoing debates on economic growth effects on poverty reduction, the correlation between income distribution and poverty, feasibility of policies implication on poverty reduction, and problems related to measurement and interpretation of the trend. There were neither solid results nor uniform views on the problem and trend while we found each of the studies substantial in its own right. It is worthwhile for policy makers in the Asian region to take each finding from these studies into account when pursuing policy initiatives for inclusive growth.

\subsection{Economic Growth and Poverty Reductions}

The large portion of poverty studies focused linkage of economic growth and poverty reduction and income distribution. Those who give more weight on economic growth often emphasize the needs to give priority and to exercise the growth oriented policy. The other side however argued that policy should be designed aiming both economic growth and poverty reduction simultaneously. Each study has addressed its own insight in diagnosing the cause and problems with the reframing of growth patterns or rearranging economic resources.

Christiansen and Todo (2013) conducted an empirical analysis for 59 developing countries from 1980 to 2004 on the relationship between economic growth rate and poverty reduction. The results show that migration out of agriculture into non-farm economy and secondary towns yield more inclusive growth patterns and reduce the poverty rate more rapidly than agglomeration in mega cities. In another study, Kurita and Kurosaki (2010) using household expenditure data, conducted an empirical analysis on the relationships among growth, poverty and inequality in Thailand and the Philippines. The result shows that inequality reduced the growth rate of per-capita consumption. The different patterns of two countries' 
growth and poverty reductions can be explained by the differences in inequality.

The empirical analysis of Dollar et al. (2013) which used the data from 118 countries over the last four decades, confirms that economic growth significantly reduces poverty. The major findings from the study are: (i) as mean incomes increase with economic growth, incomes of those in the bottom percentiles of the income distribution rise proportionally, (ii) no worldwide trend towards greater inequality has been observed, (iii) because of much higher economic growth rates in Asia, the growth in income levels of the bottom $40 \%$ has been much faster than that of Latin America. The authors are unable to draw a conclusion that any particular policies are more "pro-poor" or conducive to promoting "shared prosperity".

Using data from nine Asian countries for the period 1985-2009, Perera and Lee (2013) examined the effects of economic growth and institutional quality on poverty reduction and income inequality. Empirical results show that economic growth has no significant effect on income inequality but leads to poverty reduction. Improved government stability, law and order had a positive impact on poverty reduction. The degree of corruption, accountability, and bureaucratic quality matter for reducing poverty and improving income distribution. Policy measures of improving institutional quality enables them to tackle the problems of poverty and income distribution in developing Asia.

Klasen (2009) compared the level of poverty reduction in emerging countries 1980-2005 and found that absolute poverty is immediately reduced by any kind of income redistribution policies. Since the 1990s, the pace of poverty reduction has accelerated in Brazil but slowed down in both China and India due to the rising inequality. The author argues that low initial inequality promotes subsequent growth. Rising inequality ultimately undermines economic growth by reducing welfare, attenuating social stability and slowing down the poverty reduction. Policy makers should find a way to achieve growth without altering the inequality.

Ravallion (2011) found Brazil, China, and India made reductions to poverty levels during reform periods, but the degrees and causes of such achievement varied across the countries. Despite little economic growth, Brazil achieved a high rate of poverty reduction through complementing market reforms with progressive social policies. The success of Brazil will help China to perform better fiscal policy. In case of India, assuring poor people can participate in both the growth process and social policies is suggested. The important role of macroeconomic stability in poverty reduction is relevant to all three countries.

Montalvo and Ravallion (2010) using Chinese provincial panel data found that the huge reduction in China's poverty levels since 1980 was mainly driven by the rapid economic growth. The result showed that the China's primary sector, compared with manufacturing or service sectors, hugely contributed to reducing absolute poverty while the uneven growth process across the sectors diluted the pace of poverty reduction.

Donaldson (2008) analyzed the negative exception (income growth of the poor less than expected) and positive exception (income growth of the poor exceed expected) of growth effect for 22 countries. Results revealed that in many occasions "economic growth can be achieved without reducing the poverty rate”. For negative exceptions, reckless economic growth helped the poor to a limited extent while economic recessions significantly hurt them. For positive exceptions, in spite of modest economic growth, the income of the poor increased despite growth or poverty rates declining.

While debates on how economic growth has effected poverty reduction in developing Asia, the distribution of income has not yet led to a concrete conclusion. Most studies agreed that "the quality of the growth does matter" which requires policy to be designed to accommodate 
both economic growth and poverty reduction simultaneously to pursue policy initiatives for inclusive growth.

\subsection{Poverty Reduction Trends and Measurement}

Chandy et al. (2013) studied how future poverty trends may unfold over the coming year. They compared the base line scenario and their alternative scenario on the expected degree of extreme poverty elimination by 2030 . Based on the level of progress achieved so far, they viewed that a similar range of progress can be achieved as long as there is equity growth. India is expected to drive global poverty reduction over the coming decade. In general, they do not oppose what has been discussed on the level of poverty by 2030, but note that one cannot say for certain that these global rates of development can be sustained in the long run.

Sumner (2010) argued that the global poverty problem has changed because most of the world's poor no longer live in low-income countries (LICs). Previously, poverty was viewed predominantly as an LIC issue; nowadays such simplistic classifications are misleading. According to Chen and Ravillion (2012) who used household survey data from 125 countries for the period of 1979-2011, although progress has been uneven across the regions, the developing world has achieved a higher degree of decline both in absolute and relative poverty since the 1990s. The result shows that while the number of absolutely poor has fallen since the 1990s, the ranges of improvement have been fluctuating.

The OECD (2008) reported that income inequality of OECD countries has increased over the past two decades. No matter what kinds of measurement are implied, some countries are more unequal in their income distribution. There was also a widespread increase in poverty levels. Since 2000, Canada, Germany, Norway, the U.S., Italy, and Finland showed significant increases in income inequality while the U.K., Mexico, Greece and Australia achieved a reduction in income inequality. Income poverty among the elderly has decreased while the contrary result holds for young adults and families with children.

The OECD (2013) report compared the living standard of both poor and rich people under the criteria of mean income and income distribution. Countries with a wide income distribution (U.S.) would have lower living standards than those who live in countries with lower mean incomes but more narrow distributions (Sweden). On the other hand, the opposite trend was shown to be the case of rich people living in countries where mean incomes and distributions vary (Italy and Germany). Education and health are more equally distributed than income. Including consumption taxes into the analysis may show widening inequality, but less if one considers the effects of public services.

Alkire and Foster (2009) proposed a new methodology for measurement of multidimensional poverty. It can address various components of poverty, like poor health, inadequate education, low income, precarious housing, difficult or insecure work, political disempowerment, food insecurity, which have multiple domains and vary across people, time, and context. They suggested that each country's different stages of development should be taken into account when setting targets rather than implying uniform criteria.

Ravallion and Chen (2009) found that prevailing measures of relative poverty put an implausibly high weight on relative deprivation, such that measured poverty does not fall when all incomes grow at the same rate. This stems from the assumption that very poor people incur a negligible cost of social inclusion. The study proposed a new schedule of "weakly relative" lines that relax this assumption and estimate the implied poverty measures for 116 developing countries. The authors found that there is more relative poverty than past estimates have suggested. Despite falling numbers of absolutely poor, the number 'relatively 
poor' rose over 1981-2005.

Ortiz (2007) conducted research on global asymmetric trends in inequality and poverty. By arguing that national estimates are often less reliable due to political impact from disclosure of the reality, the author suggests special caution should be paid when using national level statistics. Ortiz also reviewed the prevailing debates concerning poverty, inequality and economic growth. The author urges to mitigate debt relief, impacts of global finance, and lack of access to market at the international level. Ortiz concludes that without properly addressing the long-term structural problems, neoliberal short-term policies cannot counter the decrease in welfare, low economic growth, unemployment and high public debt.

In general, the studies that examined poverty trends, showed evidence of a substantial degree of poverty reduction in terms of absolute poverty levels, but an increasing trend of uneven income distribution. Many suggest implementing more even distribution patterns can encourage domestic demand to foster growth through the increased consumption. Many others have particularly stressed the importance of implication of proper methodology to prevent the misinterpretation of any trend and figures.

\subsection{Poverty Reductions Policy Effects}

In order to gain experience from assessment of poverty reduction policy effects, we review a selection of studies investigating the fiscal and macroeconomic policies at the individual and groups of countries both in Asia and elsewhere.

Barrientos (2013) argued that although the figures of global poverty lines and poverty gaps have shown significant improvements since 1990, the type of poverty during this time has been uneven across regions and countries. The dominant factor behind the improvements in reducing global poverty was mainly due to China effect. Maasoumi et al. (2013) conducted a stochastic dominance analysis to investigate the level of inequality that exists in China, and how relative welfare levels have changed over time and among population subgroups. The results show that continued improvements to the state of the Chinese welfare system during 2000 to 2009 were driven by a strong economic development and growth within the country. As for the income inequity, less evidence to suggest differences exist between some subgroups. Policy that favor the needs of single/divorced headed households are recommended as the effective tool for poverty reduction in China.

Fasih (2012) researched the factors behind India's rising poverty rates despite of the sound economic growth in the period. New banking policy that allows more citizens to access bank credit was suggested for India. Protecting the more vulnerable segments of the society such as the farmers and SMEs, where only limited access to credit for financing can be progressive too. Weiss et al. (2003) argued that although microfinance has positive impact on poverty reduction, it will be source of potential risk for bank's liability and expose bank customers to a great risk.

Grassmann (2011) studied both direct and adverse effects of food and fuel price increases in 2007-08 on five poor and five non-poor countries in central Asia. They investigated whether non-contributory cash transfers can minimize the negative effects of increases in food and fuel prices. Limited coverage and funding decrease the poverty program effect. Morgan (2012) argues that Asian countries need to seek for new agenda for their economic growth other than export-led growth. The problems related with export driven growth should be rendered to achieve sustainable growth. Macroeconomic policy can contribute to rebalancing growth. In Asian economies, macroeconomic polices that induce more consumption, is likely to be most successful to reduce any imbalances that exist. 
According to Cremin and Nakabugo (2012), social development and human development, especially progress towards universal education, made a significant contribution to achieving sustainable economic development. Education efforts for reducing illiteracy, health improvement, lower fertility, improved infant survival, higher labor productivity, and more rapid GDP growth are the major forces behind sustainable development. Education plays a role as both a developmental goal and a means to developments. Tarabini and Jacovkis (2012) analyze the connections between education and poverty and how the poverty reduction has been consolidated and expanded. Estimation models of poverty and education are discussed as to how different international actors have adopted the policy. It reviews the current global development agenda to identify the major conceptualization and implementation challenges. According to Cremin and Nakabugo (2012), provision of good education is essential to confine poverty. Among policy options of inclusive growth in developing Asia, ADB (2014) finds public spending on health, education, and direct transfers to be particularly successful measures in lessening an inequality

Policy Brief (2008) presented a few key points needed to be taken into account when framing development policy. Growth is necessary, but it cannot be the panacea for tackling chronic poverty. Economic growth creates source from which social change can take place and provide greater opportunities of reflecting the voices of persistently poor people. Agénor (2004) studied the links between macroeconomic adjustment and poverty. Higher levels and growth rates of per capita income, higher rates of real exchange rate depreciation, better health conditions and greater commercial openness contribute in certain extent to poverty curtail, whereas inflation, income inequality, and macroeconomic volatility have negative effects on poverty reduction. Agénor found the relationship between growth rate and poverty to be asymmetric.

The Ferreira et al. (2010) using Brazil's GDP data for a twenty-year period found service sector's growth more effective in poverty reduction than growth in the agricultural or industry sectors. Economic growth played a relatively small role in underpinning poverty reduction between 1985 and 2004. The expansion of social security and social transfers also reduced the poverty. Barrientos (2013) suggest providing direct transfers through cash and in kind are proven as the most significant antipoverty policy in developing countries. As for low and middle-income countries, direct transfers to households are most progressive. Income transfers, incorporated with human development objectives, can enhance the productive capacity of households.

Caminada and Goudswaard's (2009) provide a descriptive analysis on the efficiency of social transfers for poverty reduction in the EU. A high degree of negative correlation between the level of social expenditure and poverty has been captured. After correcting for the impact of taxes and for private social arrangements, the correlation became weaker. At the program level, family programs and child support alleviate poverty. Koch (2012) investigated how the EU development policy can properly accommodate the changes of the development landscape which varies in terms of geography of power, wealth and poverty. Two main findings, for wealthier countries, a better coordinated cross-country division of labor be implemented to avoid marginalizing some segments of the population, and the EU development policy should continuously engage with emerging and other developing countries.

Hong and Tang (2012) examined the role of macroeconomic policies during the GDP recessions period and financial downturns of 21 developing Asian economies. When attempting to counteract a GDP recession, Asian economies tend to be more reliant on fiscal 
than monetary policies. Asian Governments expanded their spending during a recession while OECD economies tried to keep equilibrium between fiscal and monetary policies. In Asia, an increase in government spending and a reduction in interest rates during a recession period were progressive. In the case of OECD countries, only monetary policies acted as progressive when they recovered from a credit contraction.

\section{Summary, Conclusion and Recommendations}

A series of articles on income inequality, poverty reduction and inclusive growth posits a number of conclusions. Although proposed remedy measures and derived conclusions are unlike case by case, most views are centered at seeking the policy options of efficient growth in tandem with equitable distribution of growth.

In advanced economies, the setback of high debts and mismatched skills of youth called for a need to integrate professional and academic education system by which high level of vocational skills can be endowed to the students WEF (2014). Both WEF (2014) and IMF (2013) suggest that securing the trust and support from the citizens through the implementation of transparent and reliable fiscal policy is requisite to have a successful policy effect. A fair and sustainable tax and redistribution system are considered as fairly effective means of achieving economic growth, enhance social protection and alleviates poverty. EC (2013) and IMF (2013) further emphasized that, the political motives of targeting both short term achievements and an immediate public support, would impede the long term economic progress. The empirical analysis on political-oriented remedies effect with efficiency of fiscal policy and economic growth would be meaningful works for further research, although its result will inflame potential debates among the participants. Having a reliable data set for such studies is a quite a challenging task too.

In an era of globalization, one country's decision to levy a higher tax rate on the wealth and capital assets, along with issues of individual and corporate tax evasion, cross border asset transfers will be something that is closely followed. Zucmzn (2013) shows that almost 8\% of the global financial wealth of households is in the custody of tax heaven countries. In Göndör and Nistor (2012), the fierce competition amongst nations for inviting more FDI to their country by offering attractive tax packages and benefit schemes is mutually conflicting with countries attempt to alleviate internal income disparity. IMF (2013) and WEF (2014) suggest that, further studies of the impacts of tax avoidance and FDI strategies of neighbors will provide a better picture on these issues. Both of them have suggested that although the process of overcoming national self-interest is challenging, global cooperation to detect cross border tax evasions should be home where countries can achieve mutually beneficial economic growth.

A large proportion of the articles dealt with the injustices associated with the dominant share of wealth of high income groups and the excessive earnings made by financial sectors' participants. The wide spread risks from the global financial crisis motivated and facilitated ferocious discussion about this end. IMF (2013) report states that, tax policy changes aimed at particular groups has no evident effect on scaling down an income inequality, and its distribution effect of wealth is even less clear. The studies of income tax found that advanced economies are prone to raise their tax revenue by imposing higher marginal rates to the highest income group. The effects of changes in personal and corporate income taxes show significant short-term output effects (Mertens and Ravn, 2013). The IMF (2013) report suggests that, personal income tax has performed larger multipliers effect than that of corporate income tax. 
Taxation of the financial sector has engrossed considerable attention from academia and international institutions. The marginal tax on capital income is revealed as very progressive because the richer groups are imposed a higher tax rate. The debates on this particular issue are still unending. Discussion on the fiscal devaluation, especially an empirical analysis of EC (2013), shows that fiscal devaluation is a temporal complement for remedy of economic downturn with very limited effect on structural reform. As for the consumption tax such as VAT, its impact on workers' welfare was regressive regardless of types or marginal rate of tax. As evidenced in IMF (2013) and Eurostat (2013) reports, as to the fiscal consolidation effect, few countries raised property taxes within a limited scope and its impact on wealth distribution has been mixed.

Provision of direct transfers through cash and in kinds, are demonstrated as the most effective antipoverty policy, particularly in developing countries. Provision of an easy access to the financial market, especially countries like India, and an expansion of education opportunity to the poor, were recommended as useful poverty reduction measures. The counter arguments on the other hand, such as Caminada and Goudswaard's (2009), show a high degree of negative correlation between the levels of social expenditure and poverty reduction. We find this issues reserve a further investigation.

Policies adopted by the countries and their experience will be a good lesson for policy makers in achieving inclusive growth of their countries. While the global poverty line and poverty gap have reduced significantly since 1990, the performance rate has been uneven across regions and countries. The studies here discussed economic and social policies toward the poverty reduction, remedies for income inequality and proposed various measures for accomplishing a more inclusive growth. The policy, that can alleviate poverty level and expand distributive effect, is ultimately progressive in long term prospective.

Depending on each nation's circumstance, policy would have different effect thus solutions need to be tailored in accordance with individual country's status (ADB, 2014). Policy of quality growth which can smooth out growing unemployment rates and widening income gaps has been recommended by many studies. While no single policy can be panacea for curing all problems at once, we find that the evidence-based policy planning and implication are home for Asia government to successfully target the inclusive growth.

\section{References}

Agénor, P.R. (2004), "Macroeconomic Adjustment and the Poor: Analytical Issues and Cross-Country Evidence”, Journal of Economic Surveys 18(3), 351-408.

Agnello, L., Sousa, R.M. (2012), "How Does Fiscal Consolidation Impact on Income inequality?”, Review of Income and Wealth, DOI: 10.1111/roiw.12004.

Alesina, A.F., Ardagna, S. (2009), "Large Changes in Fiscal Policy: Taxes versus Spending”, NBER Working Paper Series 15438.

Alkire, S., Foster, J. (2009), “Counting and multidimensional poverty measurement”, Oxford Poverty \& Human Development Initiative, Working Paper No. 32.

Antonczyk, D., DeLeire, T., Fitzenberger, B. (2010), "Polarization and Rising Wage Inequality: Comparing the U.S. and Germany”, IZA Discussion Paper No. 4842.

Ardagna, S. (2007), "Fiscal policy in unionized labor markets", Journal of Economic Dynamics \& Control 31, 1498-1534.

Asian Development Bank (ADB, 2012), "Counting the Cost, Financing Asian Higher Education for Inclusive Growth”, ISBN 978-92-9092-580-4.

Asian Development Bank outlook (ADB Outlook, 2012), “Confronting Rising Inequality in 
Asia”, ISBN 978-92-9092-607-8.

Asian Development Bank outlook (ADB Outlook, 2014), "fiscal policy for inclusive growth", ISBN 978-92-9254-453-9 (PDF)

Steriou, D., Dimelis, S., Moudatsou, A. (2014), "Globalization and Income Inequality: A Panel Data Econometric Approach for the EU27 Countries”, Economic Modelling 36, 592-599.

Atkinson, A., Leigh, A. (2010), "The Distribution of Top Incomes in Five Anglo-Saxon Countries over the Twentieth Century", Australian National University Centre for Economic Policy Research Discussion Paper No. 640.

Atkinson, A. (2007), “The distribution of earnings in OECD countries”, International Labour Review 146(1-2), 41-60.

Atkinson, A., Piketty, T, and Saez, E. (2011), “Top Incomes in the Long Run of history”, Journal of Economic Literature 49(1), 3-71.

Atkinson, A., Morelli S. (2012), "Chart book of Economic Inequality: 25 Countries 19112010”, Institute for New Economic Thinking (INET) Research Note 015.

Atkinson, A., Morelli S. (2011), “Economic Crises and Inequality”, UNDP, Research Paper 2011/6.

Balakrishnan,R., Steinberg C., Syed, M. (2013), ”The Elusive Quest for Inclusive Growth: Growth, Poverty, and Inequality in Asia, Working Paper/13/152, Asia and Pacific Department of International Monetary Fund.

Baldacci, C., Gupta, S., Granados, C.M. (2009), "How Effective is Fiscal Policy Response in Systemic Banking Crises?” IMF Working Paper 09/160.

Bargain, O. (2012), "The Distributional Effects of Tax-benefit Policies under New Labour: A Decomposition Approach”, Oxford Bulletin of Economics and Statistics 74(6), 856-874.

Barrientos, A. (2013), "Inequality, Poverty, and Antipoverty Transfers", Background Research Paper for Post-2015 UN MDG Development Agenda.

Bastagli, F., Coady, D., Gupta1, S. (2012), “Income Inequality and Fiscal Policy”, IMF Staff Discussion Note SDN/12/08.

Beck, T., Demirgüç-Kunt, A., Levin, R. (2007), "Finance, inequality and the poor”, Journal of Economic Growth 12, 27-49.

Beetsma, R., Giuliodori, M., Walschot, M., Wierts, P. (2013), "Fifty years of fiscal planning and implementation in the Netherlands", European Journal of Political Economy 31, 119-138.

Bellettini, G., Delbono, F. (2013), "Persistence of high income inequality and banking crises: 1980-2010”, Quaderni - Working Paper DSE No. 885.

Belzil, C. (2007), “Testing the Specification of the Mincer Wage Equation”, Institute for the Study of Labor (IZA) March 2007 Discussion Paper 2650.

Bénétrix, A.S. (2012), "Fiscal Shocks and Real Wages” International Journal of Finance and Economics, 17, 203-220.

Bergh, A., Nilsson, T. (2010), "Do liberalization and globalization increase income inequality?”, European Journal of Political Economy 26, 488-505.

Bertola, G. (2010), Inequality, integration, and policy: issues and evidence from EMU.

Bonfiglioli, A. (2012), "Investor protection and income inequality: Risk sharing vs. risk taking”, Journal of Development Economics 99, 92-104.

Bouvet, F. (2010), "EMU and the dynamics of regional per capita income inequality in Europe”, Journal of Economic Inequality 8,323-344.

Bowlus, A.J., Robin, J-M. (2012) An International Comparison of Lifetime Inequality: How Continental Europe Resembles North America”, Journal of the European Economic Association, 10(6), 1236-1262.

Brzozowski M., Gorzelak, J.S. (2010), “The Impact of Fiscal Rules on Fiscal Policy 
Volatility”, Journal of Applied Economics 8(2), 205-231.

Caminada, K, Goudswaard, K. (2009), "Effectiveness of Poverty Reduction in the EU: A Descriptive Analysis", Poverty \& Public Policy 1(2), Article 5.

Card, D., DiNardo, J.E. (2002), "Skill-Biased Technological Change and Rising Wage Inequality: Some Problems and Puzzles”, Journal of Labor Economics 20(4), 733-783.

Carre`re, C., De Melo, J. (2012), "Fiscal Spending and Economic Growth: Some Stylized Facts”, World Development 40(9), 1750-1761.

Chandy, L., Ledlie, N., Penciakova, V. (2013), “The Final Countdown: Prospects for Ending Extreme Poverty by 2030”, Policy Paper 2013-04, The Brookings Institution.

Checchi, D., Peñalosa, C.G. (2008), "Labour Market Institutions and Income Inequality', Economic Policy 23(56), 601-649.

Checchi, D. (2000), "Does Educational Achievement Help to Explain Income Inequality? UNU World Institute For Development Economic Research (UNU/WIDER) Working Papers No. 208.

Chen, S., Ravallion, M. (2012). "More Relatively-Poor People in a Less Absolutely-Poor World.” Policy Research Working Paper 6114, World Bank.

Chiswick, B.R. (2003), "Jacob Mincer, Experience and the Distribution of Earnings", Institute for the Study of Labor (IZA), DP No. 847.

Christiansen, L., Todo, Y. (2013), "Poverty Reduction during Rural-Urban TransformationThe Role of the Missing Middle", World Development, forthcoming.

Claus, I., Martinez-Vazquez, J., Vulovic, V. (2012), "Government Fiscal Policies and Redistribution in Asian Countries”, ADB Working Paper Series No. 310.

Climent, A.C. (2010),"Inequality and growth in advanced economies: an empirical investigation”, Journal of Economic Inequality 8, 293-321.

Cornia, G.A., Martorano, B. (2013), "Development policies and income inequality in selected developing regions, 1980-2010”, Working Paper N. 13/2013, University of Florence and Unicef-IRC.

Cottarelli, C., Jaramillo, L. (2013), "Walking Hand in Hand: Fiscal Policy and Growth in Advanced Economies", Review of Economics and Institutions 4(2), Article 3.

Cremin, P., Nakabugo, M.G. (2012), "Education, development and poverty reduction: A literature critique”, International Journal of Educational Development 32, 499-506.

Devereux, M.P., Johannesen, N., Vella, J. (2013), “Can taxes tame the banks? Evidence from European bank levies”, Working Paper of 69th Annual Conference of the International Institute of Public Finance (IIPF): 'The Role of the State in Growth and Development', 22/08/2013-25/08/2013, Taormina, Sicily.

Dollar, D., Kleineberg, T., Kraay (2013). "Growth Still is Good for the Poor." Policy Research Working Paper 6568. World Bank.

European Commission (2013), "Study on the Impacts of Fiscal Devaluation”, Working Paper No. 36.

Eurostat (2013), “Taxation Trends in the European Union: data For the EU Member States, Iceland and Norway Statistical Books.

Fasih, F. (2012), "Inclusive growth in India through Islamic banking”, Procedia - Social and Behavioral Sciences 37, 97-110.

Ferreira, F.H.G., Leite, P.G., Ravallion, M. (2010) "Poverty reduction without economic growth? Explaining Brazil's poverty dynamics, 1985-2004”, Journal of Development Economics 93, 20-36.

Freeman, R.B. (2010), “its financialization!”, International Labour Review 149(2), 163-183.

Gassmann, F. (2011), "Protecting Vulnerable Families in Central Asia: Poverty, Vulnerability and the Impact of the Economic Crisis”, UNU-MERIT Working Papers.

Göndör, M. and Nistor, P. (2012), “Fiscal Policy and Foreign Direct Investment: Evidence 
from some Emerging EU Economies”, Procedia - Social and Behavioral Sciences 58, 1256-1266.

Gordon, R.J., Becker, I.D. (2008), “Controversies about the Rise of American Inequality: A Survey”, NBER Working Paper Series. 13982.

Gottschalk, P., Huynh, M. (2010), “Are Earnings Inequality and Mobility Overstated? The Impact of Non-Classical Measurement Error". The Review of Economics and Statistics 92(2), 302-315.

Gottschalk, P., McEntarfer, E., Moffitt, R. (2008), "Trends in the Transitory Variance of Male Earnings in the U.S., 1991-2003: Preliminary Evidence from LEHD data” the documents prepared for presentation at the meetings of the American Economic Association, San Francisco, January 2009.

Gregorio, J.D., Lee, J.W. (2002), "Education and income inequality: New evidence from cross-country data", Review of Income and Wealth 48(3), 395-416.

Gürtzgen, N. (2009), 'Rent-sharing and collective bargaining coverage - evidence from linked employer-employee data', Scandinavian Journal of Economics 3, 323-349.

Hong, K.S., Tang, H.C. (2012), “Crises in Asia: Recovery and policy responses”, Journal of Asian Economics 23, 654-668.

International Monetary Fund (IMF, 2013), “Fiscal Monitor”, October 2013.

Jäntti, M. (1997), "Inequality in five countries in the 1980's: the role of demographic shifts, markets and government policies”, London School of Economics and Political Science.

Jomo K.S. (2006), “Growth with Equity in East Asia?”, Department of Economic and Social Affairs (DESA) Working Paper No. 33, United Nations.

Kar, S., Saha, S. (2012), "Corruption, Shadow Economy and Income Inequality: Evidence from Asia”, IZA Discussion Paper No. 7106.

Kenworthy, L., Smeeding T. (2013), “Growing Inequalities and their Impacts in the United States”, GINI Country Report United States, January 2013.

Kitao, S. (2010), "Short-run fiscal policy: Welfare, redistribution and aggregate effects in the short and long-run”, Journal of Economic Dynamics \& Control 34, 2109-2125.

Klasen, K. (2009), "Inequality in Emerging Countries: Trends, Interpretations, and Implications for Development and Poverty Reduction”, Intereconomics, November/December 2009.

Knight, J.H., Sabot, R.H. (1983), "Education expansion and the Kuznets effect", The American Economic Review 73(5), 1132-1136.

Koch, S. (2012), "From Poverty Reduction to Mutual Interests? The debate on differentiation in EU development policy” Discussion Paper, DIE Research Project, “EU Development Policy to 2020".

Kurita, K., Kurosaki, T. (2010), "Dynamics of Growth, Poverty and Inequality: A Panel Analysis of Regional Data from Thailand and the Philippines", Asian Economic Journal 25(1), 3-33.

Kuttner, K.N., Posen, A.S. (2002), "Fiscal Policy Effectiveness in Japan”, Journal of the Japanese and International Economies 16, 536-558.

Larch, M. (2012), "Fiscal Performance and Income Inequality: Are Unequal Societies More Deficit-Prone? Some Cross-Country Evidence”, KYKLOS 65(1), 53-80.

Lee, D., Saez, E. (2012), “Optimal minimum wage policy in competitive labor markets”, Journal of Public Economics 96, 739-749.

Lemieux, T. (2006), "Postsecondary Education and Increasing Wage Inequality", American Economic Review 96(2), 195-199.

Lemieux, T. (2007), “The Changing Nature of Wage Inequality”, NBER Working Paper Series, 13523.

Maasoumi, E., SU, B., Heshmati, A. (2013) “Analysis of Stochastic Dominance ranking of 
Chinese Income Distributions by Household Attributes”, Unpublished, March 20, 2013.

Manafi, A., Marinescul. D.E. (2013), "The Influence of Investment in Education on Inclusive Growth -Empirical Evidence from Romania vs. EU”, Procedia - Social and Behavioral Sciences 93, 689-694.

Martins, P.S., Pereira, P.T. (2004), "Does education reduce wage inequality? Quantile regression evidence from 16 countries”, Labour Economics 11, 355-371.

Mertens, K., Ravn, M.O. (2013), "The Dynamic Effects of Personal and Corporate Income Taxes in the United States,” American Economic Review 103(4), 1212-1247.

Milanovic, B. (2009), "Global Inequality Recalculated the Effect of New 2005 PPP Estimates on Global Inequality”, World Bank Development Research Group, Poverty and Inequality Team, September 2009, Policy Research Working Paper No. 5061.

Montalvo, J.G., Ravallion, M. (2010), "The pattern of growth and poverty reduction in China”, Journal of Comparative Economics 38, 2-16.

Mookerjee, R., Kalipioni, P. (2010), "Availability of financial services and income inequality: The evidence from many countries”, Emerging Markets Review 11, 404-408.

Morgan, P.J. (2012), “The role of macroeconomic policy in rebalancing growth”, Journal of Asian Economics 23, 13-25.

Muinelo-Gallo, L., Roca-Sagalés, O. (2011), "Economic Growth and Inequality: The Role of Fiscal Policies”, Australian Economic Papers 50(2-3), 74-97.

Muinelo-Gallo, L., Roca-Sagalés, O. (2013),' Joint Determinants of Fiscal Policy, Income Inequality and Economic Growth”, Economic Modelling 30, 814-824.

Nolan, B., Marx I., Salverda, W. (2011), “Comparable Indicators of Inequality across Countries”, Growing Inequalities’ Impacts, Gini Discussion Paper 9, March 2011.

Organisation for Economic Co-operation and Development (OECD, 2013), "Choosing Fiscal Consolidation Instruments Compatible with Growth and Equity,” Economic Policy Papers No. 07.

Organisation for Economic Co-operation and Development (OECD, 2008), "Growing Unequal? Income Distribution and Poverty in OECD Countries”.

Ortiz, I. (2007), “Poverty Reduction”, MPRA Paper No. 31961.

Osberg, L. (2013), "Instability implications of increasing inequality: Evidence from North America”, Economic Modelling 35, 918-930.

Peñalosa, C.G., Orgiazzi, E. (2013), "Factor Components of Inequality: A Cross-Country Study”, Review of Income and Wealth 59(4), 689-728.

Peñalosa, C.G. (2010), "Income distribution, economic growth and European integration”, Journal of Economic Inequality 8, 277-292.

Peñalosa, C.G., Turnovsky, S.J. (2011), “Taxation and Income Distribution Dynamics in a Neoclassical Growth Model”, Journal of Money, Credit and Banking 43(8), 1543-1577.

Perera, LD.H., Lee, G.H.Y. (2013), "Have economic growth and institutional quality contributed to poverty and inequality reduction in Asia?”, Journal of Asian Economics 27, 71-86.

Piketty, T., Saez, E. (2001), “Income Inequality in the United States, 1913-1998”, NBER Working Paper 8467.

Policy brief (2008), “Escaping chronic poverty through economic growth”, Policy Brief, No. 8 July 2008, Chronic Poverty Research Centre.

Prieto-Rodríguez, J. and Gabriel Rodríguez, J. (2010), "Income Mobility and Economic Inequality from a Regional Perspective”, Journal of Applied Economics 8(2), 335-350.

Rada, C., Kiefler, D. (2013), "A note on the wage share in OECD countries: Is there a race to the bottom?”, Working Paper 2013-13, Department of Economics, University of Utah.

Ravallion, M., Chen, S. (2009), "Weakly Relative Poverty Policy”, Research Working Paper 4844, World Bank, Development Research Group. 
Ravallion, M. (2010), “A Comparative Perspective on Poverty Reduction in Brazil, China, and India”, World Bank Research Observer 26(1), 71-104.

Rodgers, Y.M., Zveglich, Jr., J.E. (2012), Inclusive Growth and Gender Inequality in Asia’s Labor Markets, ADB Economics Working Paper Series, No. 321,

Silva, R., Carvalho, V.M., Ribeiro, A.P. (2013), "How Large are Fiscal Multipliers? A PanelData VAR Approach for the Euro Area”, FEP Working Papers, No. 500 August 2013.

Smeeding. T.M., Thompson, J.P. (2010), "Recent Trends in the Distribution of Income: Labor, Wealth and More Complete Measures of Well Being”, Political Economy Research Institute (PERI), University of Massachusetts Amherst.

Sologon, D.M., O’Donoghue, C. (2009), "Equalizing or Disequalizing Lifetime Earnings Differentials? Earnings Mobility in EU: 1994-2001”, SOEP No 251.

Stiglitz, J.E. (1982). "Self-selection and Pareto efficient taxation", Journal of Public Economics, 17, 213-240.

Stiglitz, J.E. (2012a) "The Price of Inequality", Article, 37(11), NEWS and Ideas for the Columbia Community June 21, 2012.

Stiglitz, J.E. (2012b), The Price of Inequality, W. W. Norton \& Company New York, London.

Stockhammer, E. (2013), "Why have wage shares fallen?: "A panel analysis of the determinants of functional income distribution”, ILO, Conditions of Work and Employment Series No. 35.

Sumner, A. (2010), "Global Poverty and the New Bottom Billion: What if three-quarters of the World's Poor Live in Middle-income Countries?”, Brighton IDS ( Institute of Development Studies ), Working Paper 349.

Sylwester, K. (2000), “Income inequality, education expenditures, and growth”, Journal of Development Economics 63, 379-398.

Tarabini, A., Jacovkis, J. (2012), “The Poverty Reduction Strategy Papers: An analysis of a hegemonic link between education and poverty”, International Journal of Educational Development 32, 507-516.

Teulings, C., Rens, T.V. (2005), “Education, Growth and Income Inequality”, Version 2003 and version 2005, Tinbergen Institute Discussion Paper, TI 2002-001/3.

Thompson, J.P., Smeeding, T.M. (2013), "Inequality and Poverty in the United States: the Aftermath of the Great Recession”, Finance and Economics Discussion Series Divisions of Research \& Statistics and Monetary Affairs Federal Reserve Board, Washington, D.C.

United Nations (UN, 2013), "The Twin Challenges of Reducing Poverty and Creating Employment”, United Nations publication, ST/ESA/342.

United Nations Development Programme (UNDP, 2013), "Fast Fact- Poverty Reduction and UNDP” International Policy Centre for Inclusive Growth, Poverty Practice, Bureau for Development Policy.

Wade, R.H. (2004), “Is Globalization Reducing Poverty and Inequality?” World Development 32(4), 567-589.

Weiss, J., Montgomery, H., Elvira, K. (2003), "Micro finance and poverty reduction in Asia: what is the evidence?”, ADB Institute Research Paper Series No. 53.

Willen, P., Shapiro, J., Hendel, I. (2005), "Educational opportunity and income Inequality”, Journal of Public Economics 89, 841-870.

Wolf, E.N., Zacharias, A. (2007), "The Distributional Consequences of Government Spending and Taxation in the U.S., 1989 and 2000”, Review of Income and Wealth 53(4), 692-715.

Woo, J. (2011), “Growth, income distribution, and fiscal policy volatility”, Journal of Development Economics 96, 289-313

World Economic Forum (2014), “Global Risks 2014, Ninth Edition”.

Yoshida, N., Uematsu, H., Sobrado, C.E. (2014), "Is Extreme Poverty Going to End? An 
Analytical Framework to Evaluate Progress in Ending Extreme Poverty”, Policy Research Working Paper 6740, World Bank Poverty Reduction and Equity Unit.

Zucman, G. (2013), "The Missing Wealth of Nations: Are Europe and the U.S. Net Debtors or Net Creditors?”, Quarterly Journal of Economics 128(3), 1321-64. 